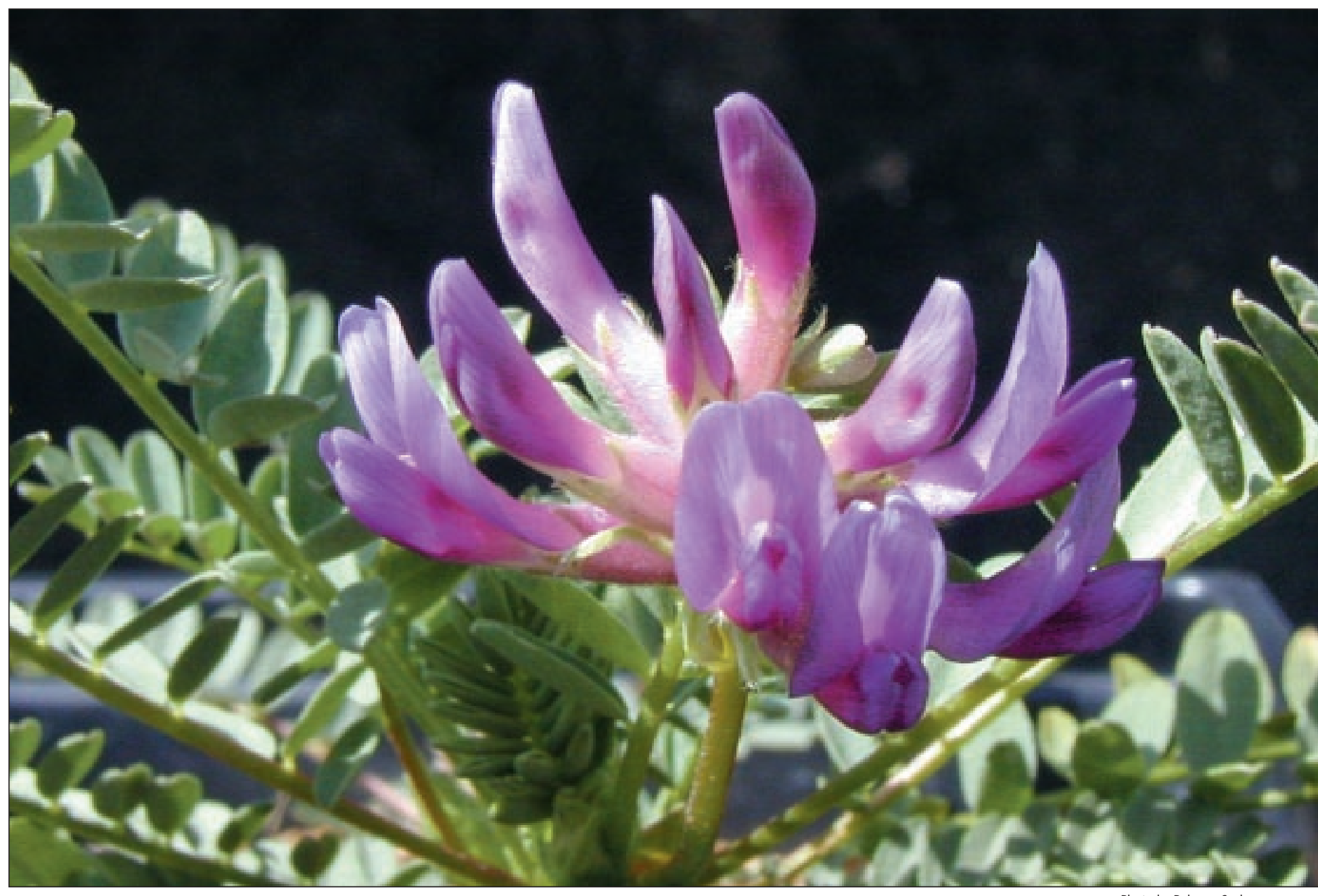

\title{
Propagation Protocol for Astragalus bibullatus
}

\author{
Kimberlie McCue, ERIC Belt, \\ AND MARY YURLINA
}

KEY WORDS: endangered plant, Center for Plant Conservation

\section{NOMENCLATURE: USDA NRCS (2001)}

The genus Astragalus L. (Fabaceae) or milkvetch includes well over 1000 species worldwide. With over 350 species native to the US alone, Astragalus is one of the largest genera of flowering plants in the Northern Hemisphere. These fetching legumes have flourished in seemingly hostile environments-parched mountains, steppes, glades, and barrens-where substantial root systems and nitrogen fixing nodules no doubt come in handy. With such distinct and often isolated habitats, it is no surprise that there are so many species of Astragalus and that many are rare.

The Center for Plant Conservation, a network organization devoted to conserving America's rare native plants, tracks data for nearly 250 species of Astragalus in the US. Twenty members of this genus have been received into CPC's National Collection of Endangered Plants, where plants are conserved as seeds and studied in cultivation so that they may some day be restored to the wild. For example, seeds from populations of Barr's Milkvetch, A. barrii Barneby, are being maintained under controlled conditions at The Nebraska Statewide Arboretum, a CPC 
member. In the 50 or so years since $A$. barrii was discovered, less than 100 populations have been found in South Dakota, Wyoming, Montana, and Nebraska. Its cushiony, mounded growth form, silvery foliage and red flowers make this an attractive species to horticulturalists for cultivation in xeriscapes. Osterhout's milkvetch, or A. osterhoutii M.E. Jones, is grown at Denver Botanic Gardens, another member of the CPC network. This species is known only from a 24square $\mathrm{km}$ (15-square mile) range in Grand County, Colorado, where crested wheat grass (Agropyron desertorum (Fisch. ex Link) Schult), an introduced species, threatens its survival. At the Holden Arboretum near Cleveland, Ohio, growing the rare $A$. tennesseensis Gray ex Chapman involves inoculating seedlings with the nitrogen-fixing bacterium that makes its home in the plant's roots.

An exciting victory for rare plant propagation has just occurred at the Missouri Botanical Garden (MBG), where CPC is headquartered. Astragalus bibullatus Barneby \& Bridges, also known as Pyne's ground plum or limestone glade milkvetch, has, for the first time, been grown to maturity from seed. This is a significant achievement in efforts to preserve the species. Astragalus bibullatus is a federally endangered species known from only 3 populations occurring on cedar glades in Tennessee's Central Basin. These glades occur on thinbedded, fossiliferous limestone outcroppings. Within this setting, $A$. bibullatus is rooted in narrow crevices in the bedrock, mainly along the glade margins, often partially shaded by the cedars. Many attempts had been made to propagate plants from seeds, but all were unsuccessful. Then, by mimicking conditions the plant encounters in the wild, workers at MBG were able to bring the plants through the critical first few weeks after germination. Two years have passed since that success and not only have the plants from those trials survived, many flowered for the first time in March 2001. Further, MBG entered into collaboration with the Tennessee Department of Environment and Conservation, the US Fish and Wildlife Service, and the National Park Service to establish a new colony of $A$. bibullatus in

Tennessee. The first seedlings produced by MBG for this project went into the ground this spring.

For this project, we collected seeds in June 2000. In July, seeds were scarified with 100-grit garnet sandpaper and then soaked in warm water $(-38$ $\left.{ }^{\circ} \mathrm{C}\left[100^{\circ} \mathrm{F}\right]\right)$ for about $1 \mathrm{~h}$. Scarification should be intense enough to partially expose the cotyledons. Seeds were then sown just below the surface of the growing medium.

The growing medium proved to be key to the successful propagation of $A$. bibullatus. Previous attempts to cultivate this species made use of a standard horticultural medium (for example, Redi-Earth [The Scotts Company, Marysville, Ohio]). However, this medium is relatively heavy and retained moisture, probably contributing to the rapid demise of seedlings through damping-off. Therefore, we attempted to create a soil medium that would more closely mimic the rocky, well-drained soil of the plants' native habitat. A new growing medium was devised by combining 3 parts coarse filter sand (\#816 General Material Company, St Louis, Missouri) and 1 part Redi-Earth Plug and Seedling Mix $(55 \%$ to $65 \%$ sphagnum peat moss and $35 \%$ to $45 \%$ medium grade vermiculite).

We planted 2 seeds into individual cavities of TLC Pro-Tray 72 (cavity depth $5.9 \mathrm{~cm}$ [2.3 in], top diameter $3.8 \mathrm{~cm}$ [1.5 in], bottom diameter 2.1 $\mathrm{cm}$ [0.8 in]; TLC Polyform Inc, Woburn, Massachusetts). Until germination (usually within 4 to $7 \mathrm{~d}$ ), the medium was kept moist by watering from above. Thereafter, seedlings were watered only when the medium was completely dry, and watering was done from below. Trays containing seedlings were placed into tubs filled with water $(\mathrm{pH}-8.5)$ allowing the water to "wick up" through the growing medium.

After approximately $8 \mathrm{wk}$ (September), seedlings were transplanted into individual cells (Com-packs 804; $5 \mathrm{~cm} \mathrm{X}$ $5 \mathrm{~cm} \mathrm{X} 5 \mathrm{~cm}$ [2 X 2 X 2 in]) filled with a fresh mix of filter sand and Redi-Earth.

Seedlings were not fertilized the first 8 wks, but after transplanting seedlings were watered from below 1 to 2 times each week with a $150 \mathrm{ppm}$ $\mathrm{N}$ solution (Miracle-Gro Excel, $15 \mathrm{~N}: 5 \mathrm{P}_{2} \mathrm{O}_{5}: 15 \mathrm{~K}_{2} \mathrm{O}$ Cal-Mag; The Scotts Company, Marysville, Ohio).

Greenhouse temperatures for germination and seedling growth were 18 to $20{ }^{\circ} \mathrm{C} \pm 2\left(65\right.$ to $\left.70{ }^{\circ} \mathrm{F} \pm 5\right)$. In initial experiments, some seedlings were placed in full sun while others were grown under 30\% shade cloth. This experiment was repeated twice and either way works well. Subsequent cohorts have been grown in full sun. In November 2000, all plants were moved to a "cold" greenhouse where conditions were 4 to $18{ }^{\circ} \mathrm{C} \pm 2$ (40 to $\left.65^{\circ} \mathrm{F} \pm 5\right)$. Plants overwintered in the cooler conditions.

For our Tennessee project, plants were outplanted in March 2000. They will be monitored at periodic intervals. Seedlings from the original propagation experiments kept at Missouri Botanical Garden flowered when they were 20 months old.

\section{REFERENCE}

USDA NRCS. 2001. The PLANTS database, Version 3.1 (on-line database). URL: http://plants.usda.gov (accessed 26 Jun 2001). Baton Rouge (LA): National Plant Data Center.

\section{AUTHOR INFORMATION}

Kimberlie McCue

Conservation Coordinator

kimberlie.mccue@mobot.org

Eric Belt

Conservation Intern

Missouri Botanical Garden

4344 Shaw Blvd

St Louis, MO 63110

Mary Yurlina

Conservation Programs Manager Center for Plant Conservation

4344 Shaw Blvd

St Louis, MO 63110

mary.yurlina@mobot.org 